\title{
The Concept of Brand Culture: A Qualitative Analysis Directed to Turkish Airlines
}

\author{
Deniz Maden \\ Ege University / Turkey \\ Faculty of Communications \\ Research Assistant \& PhD Candidate
}

\author{
Doi:10.5901/mjss.2013.v4n10p42
}

\begin{abstract}
Culture is an important aspect of branding studies. There is a mutual relationship between culture and brands: While culture and cultural perspectives have strong effects on branding, brands also have serious effects on culture. The concept of 'brand culture' refers to the cultural codes developed by brands. A brand's culture indicates the set of values which create that brand's inspirational power. This study covers the relationship between brands and culture and the concept of brand culture. A qualitative research has been carried out focusing on Turkish Airlines (THY), which was chosen to be the best airline company of Europe in 2012. Research objectives are determined as: to point out the effects of culture on THY, to display how culture is used by the brand, to define the brand culture and its represantation in intercultural environments. Finally, to compare the diverse perceptions from the point of view of the brand and the customer. Primary information for the qualitative analysis has been based on interviews made with the brand manager of Turkish Airlines and a customer of THY. Secondary information for the case has been gathered via the corporate website and articles about the brand. Content analysis was applied to the data by composing the codes and themes, and finally the results have been reported.
\end{abstract}

Keywords: Cultural approach to brand management, intercultural management, brand culture, Turkish Airlines

\section{Literature Review}

In the literature review, first, the mutual relationship of culture and brands is mentioned. Afterwards, the concept of brand culture and its importance in branding are described. Finally, factors forming and affecting brand culture are undertaken.

\section{Relation of Culture and Brands}

Brands are formed of tangible and intangible elements. They do not just include physical and visual attributes, but also socio-psychological attributes, beliefs and values. Managing brands successfully is possible by managing the brand's hollistic meaning in the marketplace (Schroeder, 2009: 125). At this point, culture plays an important role in managing this holistic system of meaning. Organizations and brands are networks which can not be evaluated without their cultural context. Therefore, marketing and branding are not just business processes but also cultural processes (Holt, 2003a, Firat \& Dholakia 2006). Cultural codes have effects on the branding process and on the meanings created by the brand.

Brands are driven by a culture, while at the same time they transfer this culture. Thus, there is a two-sided mutual relationship between brands and culture where culture affects brands and brands transmit culture.

Cultural assets form core values of brands and create their identities (Kapferer, 2008: 184). Cultural values differentiate a brand among its competitors. For example, very well known two sports brands Nike and Adidas are differentiated mainly according to their cultural values. Though these two brands are very similar with their product categories, physical attributes and main proposals, consumers' interpretations of these brands differ according to their cultural values that they attach to them. While Nike is related to competitiveness, Adidas is more focused on authenticity.

Brands have strong roles in transmitting culture. Brands infuse culture with meaning in the branded world that we live in (Shroeder, 2007). Strong brands become cultural icons and address a culture's core sensibilities such as national myths (Närvänen, 2011). Some brands become very strong cultural artefacts and are identified with their country and culture. These brands come up as one of the first things to be related with that country. BMW, Mercedes connoting Germany, Gucci, Ferrari reminding of Italy or McDonald's being related with USA are examples of these brands. 


\section{Brand Culture}

As well as being affected by culture, a brand itself presents a cultural asset. "The concept of 'brand culture' refers to the cultural codes developed by brands at a significant level (history, images, myths, art, communities, beliefs), that influence the comprehension and the value of a brand on the market (Barbu, 2012: 47)". Brand culture refers to the combination of elements which identify and distinguish products or services. These elements include names, nouns, logos, symbols, designs, all cultural traits and cultural phenomena wihin these elements, as well as the cognition, emotional attributes, cultural traditions and individual images represented by these cultural traits and phenomena. Brand culture is the core of a brand, it is a refined essence of the company's culture and it displays the fundamental value of a brand.

Brand culture shapes how customers understand the value of a product/service, and how they experience it. The value condensed in the brand attracts consumers and they accumulate pleasure and confidence in the culture of a brand (Yan, 2011). Brand culture affects the senses of the customers, and thus, their consumption experience (Holt, 2003b:4). In other words, brand culture affects the most critical features of contemporary brands: the experience and the value.

Brand cultures accumulate as four primary types of authors create stories that involve the brand. These authors are: companies, popular culture, influencers and customers (Holt, 2003b). Companies create the brand culture with their marketing mix. All elements of the marketing mix (product, place, promotion, price) tell stories about the products/services. Popular culture shapes the meanings and perceptions of brands. How the media presents or refers to brands (through television, films, magazines, internet, games etc.) will affect them as cultural assets. While customers consume the product, they interact with it, create consumption stories, and share their stories and experiences. Therefore, they take part in creating the brand culture. Influencers are people who have the power to affect other people's decisions about brands. So their ideas and influence affect the culture of a brand.

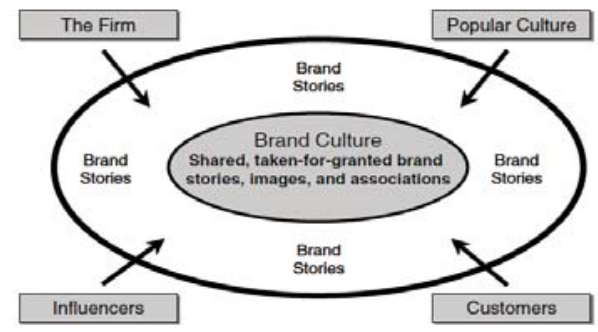

Figure 1: Formation of Brand Culture

Source: Holt, Douglas B. 2003b. Brands and Branding. Cultural Strategy Group: http://culturalstrategygroup.com/wpcontent/uploads/2010/10/brands-and-branding-csg.pdf

Brand cultures are affected and formed of many cultural elements. These include: consumer behaviour and cultural differences, effects of the national culture, country of origin effects, marketing strategy (standardization or customization), intercultural management, language, perceived globalness and relation to corporate culture. The academic literature shows that consumer behaviour is strongly shaped by cultural differences. Cultural differences affect brand positioning, consumer decision-making processes, consumption and usage of products and services, service quality perceptions, brand choices, consumer evaluations of brand extensions, diffusion of innovations and consumer response to advertising (Buil, Chernatony, Hem, 2009; de Mooij, 2000; de Mooij and Hofstede, Dwyer et al., 2005; 2002; Erdem et al., 2006; Roth, 1995; Leo et al., 2005; Witkowski and Wolfinbarger, 2002). For example, a reaction of a European consumer and an Asian consumer would not be the same. Brand cultures are strongly affected by national culture which is defined as the "collective programming of the mind (Hofstede, 1980)". Brand images are formed by national values, myths, beliefs and perceptions about country of origin effects. For example as a country of origin, Italy is related with aesthetics and this image of the country is transfered to Italian brands. Brand culture is also shaped according to the global marketing strategy. A brand can either use standardized of customized offerings for different cultural environments. Many brands choose to mingle these two approaches in their offerings. Though the core cultural messages carried by a brand may be the same in different cultures, fundamental features of the relative culture should be respected. This is the fundamental principle of intercultural management. Language, as one of the most important aspects of culture stand out as an 
important element of brand culture. How a brand's name sound and mean in different cultures is an important aspect. Some companies choose to use the same brand name for all markets, but others differentiate according to countries. For example, Unilever's cleaning liquid is called Vif in Switzerland, Viss in Germany, Jif in Britain and Greece, and Cif in France (Palumbo \& Herbig, 2000 as cited in Harun, et. al., 2011: 286). Brand's perceived globalness affects its success, if the perceived globalness is high, the brand's reputation tends to be higher. Finally, as the basis of brand culture, corporate culture has an influence on the establishment of brand culture (Yang, 2010: 223). Corporate culture and brand culture are very close concepts by affecting and complementing eachother.

\section{A Qualitative Analysis Directed to Turkish Airlines}

To be able to display the relation of brands and culture within the case of a brand, Turkish Airlines has been chosen. Turkish Airlines was established in 1933 by the founder of the Turkish Republic, Mustafa Kemal Atatürk. The international flights started in 1967. In April 2006, it became a member of the world's biggest airline association, Star Alliance. In 2012, Turkish Airlines was chosen to be the best airline company of Europe. Currently, Turkish Airlines is one of the most profitable airline companies in the world (www.turkishairlines.com).

Method: The main research question of this study is to discover the relationship between brands and culture and the concept of brand culture Along with the research question and in correspondance with the nature of this qualitative research, case study design has been used. For describing a culture which people are not familiar with the setting, providing a qualitative profile is an appropriate decision (Patton, 2002: 236). For this purpose, THY has been chosen as the sample of this research by using typical case sampling from purposive sampling types. THY was chosen due to the facts that; it is a brand which has strong cultural roots and it is one of the most important Turkish brands. To investigate the research question from the point of view of the brand, an interview has been made with the brand manager of THY (S.Ö.). To investigate the research question also from the point of view of a customer, an interview has been made with a customer of THY. The chosen customer has travelled with THY domestic flights for many times and also travelled from Turkey to USA and Turkey from several European countries in the recent two years. The interviewee will be referred to as M.T. in this article. Due to geographical and limited time problems, interviews could not be made face to face. The interview questionnaires were sent to the interviewees via e-mail and the responses were delivered in the same way. Content analysis was applied to the data by composing the codes and themes and finally the results have been reported. To increase the credibility of the study, $20 \%$ percent of the data has been analysed by another expert and it turned out that more than $70 \%$ percent of the codes determined by the expert and the researcher were similar. Secondary information for the research has been gathered via the corporate website of Turkish Airlines and articles about the brand.

Objectives of the research: Along with the main research question of this study 'discovering the relationship between brands and culture and the concept of brand culture', research objectives are: to point out the effects of culture on THY, to display how culture is used by the brand, to define the brand culture of and it's represantation in intercultural environments. Finally, to compare the diverse perceptions from the point of view of the brand and the customer.

Findings and Discussions: The interview data has been content analysed. Data attained from the interview with the brand manager has resulted in five main themes: The relation of culture and THY, brand culture of THY, intercultural management, brand communication and THY and brand culture and corporate target audiences. Data attained from the interview with the customer has formed seven main themes. Five themes turned out to be the same: The relation of culture and THY, brand culture of THY, intercultural management, brand communication and THY and brand culture and corporate target audiences. Also, two different themes were formed: brand image and Turkish customers' choices.

\subsection{Relation of Culture and Turkish Airlines}

The brand manager of THY defines the relationship between brand and culture as follows: "There is a mutual relationship between brand and culture. Culture include values created in the process of historical and social development and the tools used to transmit these values to next generations. Ignoring the dominant culture of the society will have negative results on the success of the brand". It is much more easier and faster to be accepted for a long term by consumers as a brand which gives importance to the generally accepted values of the society. Therefore, a local and a global brand needs abstract brand values appropriate to the social, cultural and psychological features of the target audiences.

He defines the relationship of culture and brand within the case of THY as follows: "THY has an important place in the history and culture of the Turkish society and it is a brand which creates important effects with its history and cultural 
codes". Consumers' commitment to the company increases due to THY being the first Turkish airline company and with all historical associations of the brand.

It is within THY's strategic priorities to create brand advantage which is formed of Turkish society's values. Especially within the service sector, the way the service is presented should affect people as a ritual and an experience, and thereby create loyalty. Turkish cultural heritage presents many precious oppurtunities and differentiating points for services and THY is trying to nourishe from these.

THY customer M.T., also shares the same opinion about the mutual relationship of brands and culture - being affected by the culture and affecting it. She indicates the cultural traces visible on the brand elements of THY and Turkish culture's strong effects on the brand. According to her, cultural influence has been a main part of the branding process of THY. In other words, the successful branding proces has been strongly grounded on using Turkish cultural elements. She also designates that not only THY has been influenced by the Turkish culture, but also THY has effects on Turkish culture as a strong brand.

\subsection{Brand Culture of Turkish Airlines}

According to S.Ö. the brand culture of THY: creates a priviliged journey experience with its brand identity which combines the hospitality and warmth of its local culture with dynamism and innovative approaches shown in all contact points with customers. He adds that this definition is a good example of the brand's positioning and how the brand's cultural heritage is effectuated. The cultural codes of THY mentioned by S.Ö. may be seen in Table 1.

Table 1: The Cultural Codes of Turkish Airlines Mentioned by the Manager

\begin{tabular}{|c|c|c|c|c|c|}
\hline Customer Centric & Prestigious & Reliable & Visionary & Entertaining & Global \\
\hline $\begin{array}{l}\text { *Traditional hospitality } \\
\text { *Friendliness } \\
\text { *Solution } \\
\text { oriented } \\
\text { *Concerned-thoughtful } \\
\text { ×Easily accessible }\end{array}$ & $\begin{array}{l}\text { *Takes work } \\
\text { seriously } \\
\text { *Priviliged } \\
\text { *Has "the most" }\end{array}$ & $\begin{array}{l}\text { *Has standards } \\
\text { *Consistent } \\
\text { *Disciplined } \\
\text { *Experienced } \\
\text { *Informed } \\
\text { *Punctual }\end{array}$ & $\begin{array}{l}\text { *Innovative } \\
\text { *Dynamic } \\
\text { *Energetic } \\
\text { *Initiator } \\
\text { *Admirable }\end{array}$ & $\begin{array}{l}\text { *Presents rich } \\
\text { treatment } \\
{ }^{\star} \text { Fun } \\
{ }^{\star} \text { Comfortable } \\
\text { *Full of nice } \\
\text { surprises }\end{array}$ & $\begin{array}{l}\text { *Many alternative of } \\
\text { flights network } \\
\text { *Presents the synthesis } \\
\text { of the east and the west } \\
\text { *Multi-cultural } \\
\text { *Niche and } \\
\text { private routes }\end{array}$ \\
\hline
\end{tabular}

Source: Interview with the brand manager of Turkish Airlines

According to S.Ö., THY reflects the Turkish culture to its guest by presenting the traditional values of the Turkish culture such as; hospitality, friendliness, being helpful and presenting a thoughtful and a concerned attitude. When customers relate the cultural values of the country with the brand, these values for THY come out to be: rich cultural heritage, hospitality, friendliness, intimacy, trustworthiness, quality and being global.

Brand culture is one of the most important elements of THY's success. THY was chosen to be the best airline company of Europe in 2012 and brand culture has serious contributions to this award. The brand culture stands out with the strong effects of Turkish authenticity and its balanced presentation to its guests worldwide. With these aspects of brand culture, it has a strength to differentiate the brand among competitors.

M.T. indicates that a brand can create a culture of its own and defines the culture of THY as a mixture of the Turkish culture and the corporate culture of THY. The cultural codes of THY mentioned by M.T. may be seen in Table 2. There are common codes indicated both by the customer and by the manager. Focusing on service quality, hospitality and friendliness are seen both in both classifications. Again, strongly indicated codes by both interviewees turned out to be the mixture of tradition and modernity and the synthesis of the east and the west. M.T. strongly stressed on the lengendary perception of THY as being a brand to be proud of for Turkey and for Turkish people. 
Table 2: The Cultural Codes of Turkish Airlines Mentioned by the Customer

\begin{tabular}{|c|c|c|}
\hline Quality & Mixture of tradition and modernity & Being legendary \\
\hline $\begin{array}{l}\text { *Service quality } \\
\text { *Hospitality } \\
\text { *Friendliness } \\
\text { *Comfort }\end{array}$ & $\begin{array}{l}\text { *Synthesis of the east and the west } \\
\text { *Being proud of its past } \\
\text { * Effects of Ottoman Culture: clothes, music } \\
\text { *Turkish authenticity } \\
\text { *Religious texture }\end{array}$ & $\begin{array}{l}\text { *Being the first flying Turkish brand } \\
\text { *Cultural heritage } \\
\text { *Relating THY success with Turkey } \\
\text { *Being a Turkish brand to be proud of } \\
\text { *Showing a Turkish brand's success }\end{array}$ \\
\hline
\end{tabular}

Source: Interview with TA customer M.T.

In the study of Küçükerdoğan, et. al. (2011) where they evaluate the visual content of THY 'Globally Yours' advertising campaing, they came up with several points: They detected that messages given via color, text and visuals are: trust, comfort, quality, excellence and success. They noted that there are several elements stressed in the advertisements: the emphasis on localness and globilization at the same time, simplicity, traditionality and innovation, the emphasis on 'us', presenting an adventure and feeling of privilege.

Brand culture difuses and strengthens with many channels. Sponsorhips are one of them. THY sponsored many famous sports teams and events like; FC Barcelona, Manchester United FC, Greece's basketball club Maroussi Basketball Club and THY has also become the sponsor of a golf tournament "Turkish Airlines Challenge". There were important outcomes of these sponsorhips: THY logo and advertisements were to take place in the famous football stadiums Nou Camp and Old Trafford Stadium, THY was to film a commercial with the players of Barcelona and advertise their sponsorship all over the world (Küçükerdoğan, et. al., 2011). The sponsorship chosen create an idea on the intentions of the brand. Also, with sponsorships, THY have the chance to demonstrate its visual identity, which is an important indicator of brand culture.

To summarize the results on brand culture, it would be appropriate to indicate the common codes which were visible in data attained from the content analysis of the both interviewees and from the secondary data. These codes of THY's brand culture turned out to be: Turkish authenticity, hospitality, friendliness, quality, being global, cultural heritage, comfort, synthesis of the east and the west and mixture of tradition and modernity.

\subsection{Intercultural Management}

Cultural differences affect the perceptions and behaviours of consumers. Due to this fact, THY differentiates its communication messages to different regions, countries and cultures, by sticking to the main theme of the advertisement campaign and maintaining the brand's cultural elements.

An important thing is to be able to have success in different countries with the same cultural brand elements. THY manages this process with various principles and behaviour: They present close, creative and customer-centric unique experiences in all customer meeting points. These experiences lead to a meaningful long-term relationship with the customers. THY makes its guests feel priviliged and special during all their journeys and avoids being common and standard. Always presents surprises to its customers via innovations made in customer meeting points. THY is aware of social responsibility and presents sensibility in all platforms.

When operating in an international platform, it is important to know the customers from different cultures. S.Ö. indicates that THY manages this diversity with two main methods; focus group meetings and local employees. With focus group meetings, THY tries to understand the perceptions about the brand and customers' expectations from the brand. According to these, the company organizes its local operations and communication plans. Another important source of information about customers from different countries is the local employees of these countries. As a global company, THY mainly works with local employees in all countries. Thereby, they receive important information about their customers from the point of view of people of their own culture.

To manage cultural differences, brands choose to differentiate their marketing strategies for different cultures. Brands may sometimes use standardization and offer the same marketing strategy worlwide and sometimes use customization and differentiate their messages according to countries, cultures and societies. S.Ö. notes that THY chooses to mix these two different strategies. They have standard presentations and the sense of the Turkish culture in their offerings but they also actualize local implementations for products, services and communication. They believe that differentiated presentations enable their guests to feel themselves in a private, safe and joyful flight experience. THY gives importance to cultural differences in making various selections from couisine to the movies that their guests are going to watch during the flight. For example, the different cousine of Far East or Europe is always considered and the 
catering services are organized according to the diverse tastes of the flying destination. Though THY differentiates their offerings for different cultures, it is important for the brand to always keep Turkish cultural aspects and assemble these with other cultural values of their guests.

According to M.T., today TA is a global brand due to its success in intercultural management. Becoming a staralliance member, sponsorships of well-known world teams and collaboration with international airline companies were correct choices of THY in the path of becoming a global brand. According to her, THY succeeds in different cultural environments due to its high level of quality which is the same everywhere. Though company faces problems, these are never reflected to the customers. Another important advantage of THY is its wide range of flights and having direct flights to long destinations.

\subsection{Brand Communication and THY}

Brand manager of THY has mentioned the following about their brand communication:

- THY plans its brand communication activities on; legal, honest and true roots. All projects are planned according to honest competition principles and all operations are carried with professional responsibility.

- THY never uses statements or words which are not appropriate to the culture and morals of the countries which it flies to.

- THY plans all its communication campaigns without trying to benefit from consumers' trust and without exploiting their lack of information or experience. All elements that affect the buying decision of consumers are transmitted within the right time and way so that consumers will be able to perceive the messages.

- In all flight routes, THY's attitude is based on respecting cultural values. The company is sensitive about races, national roots, religion, gender, age, disability and sexual preferences. It does not benefit from unlucky situations, does not use the fear factor in communication and does not exploit any belief or emotion.

- In all communication practices of THY, it is fundamental not to give misleading messages but only the truth.

- THY never creates lack of information and does not use exaggerated offers which lead consumers to spurious ideas.

What M.T. has observed about the brand communication of THY, is that the most frequently used techniques are advertisement and sponsorships. In its advertisements THY uses cultural figures but also uses world-known celebrities to become a global brand. She also indicates that the special card for THY customers (Miles \& Smiles) is a successful element to create customer loyalty.

\subsection{Brand Culture and Corporate Target Audiences}

The interviewee M.T. mentioned one issue about this theme. According to her, THY is not very successful in communicating with its corporate target audiences. Many employees of THY have been on strike and this strike has gained a serious support from the public. However, the company did not effectuate its employees demands. This issue being stressed from a customer is fairly important. It means that brand's relation with corporate target audiences affects its customers point of view about the brand and its image.

The following section about corporate target audiences depends on the content analysis of S.Ö.'s interview. Cultural aspects of the brand has strong effects to corporate target audiences. When doing business in internatioal platforms, the synthesis of the east and the west creates a different impact. For example, Eastern countries admire that THY has a western presence while at the same time presenting the rich cultural heritage of the east. Also, the enthusiasm of the brand and employees create very strong bonds with international partners.

Brand culture also has serious effects on employees. As part of its brand identity based on globalness, THY has created an employee profile who are respectful to their customers' rituals and values of all cultures.

THY managed to increase the loyalty and motivation of its employees, and direct them to a common behavioural model. THY employees internalize the corporate cultural values and act as volunteered representatives of the brand. The positive effects of culture on employees bring out many advantages. Employees are enthusiastic about developing innovative ideas, creating business models to increase efficiency and profits, questioning and enhancing the business processes. Thereby, employees make maximum contribution to THY to reach its goals by becoming a global leader.

As a service brand, THY gives great importance to corporate culture. According to THY, corporate culture and brand culture should be nourished from the same fundamental values. The brand identified many common values both for corporate and brand culture: 
- Being customer-centric.

- Being proud of the brand that he/she is a part of.

- Maintaining the values and standards which the brand represents.

- Being aware that he/she is a represantitive of the brand and feeling responsible about this.

- Being friendly all the time.

- Creating new ideas, easily adapting to innovations.

- Seing every passenger as his/her own guest.

- Respecting every individual without discrimination.

- Believing in common mind and collaboration.

- Focusing at continual development.

- Inspiringconfidence.

- Creatingfast solutions.

- Being open to communication.

All managers and employees who represent the brand should act in accordance with these values.

\subsection{Brand Image}

Interviewee M.T. has mentioned the brand image of THY. She indicates that the brand image of THY strongly grounds on being the first flying Turkish brand and being proud of Turkey's and brands' past. She highlights that the mutual bond and trust between THY and Turkish culture-history is what really creates the positive image for the brand. She notes that this message can be seen in THY's corporate advertisements. Being a successful Turkish brand enhances THY's positive image and creates customer satisfaction in the domestic market.

\subsection{Turkish Customers' Choices}

This theme has emerged from the content analysis of M.T.'s data. She indicates that not being able to choose your food in national flights and not being able to drink alcohol in national flights create unhapiness. Another issue stressed by her is that, though there was a reaction from the Turkish public on THY's new decisions on not giving alcohol in national flights and the new cloths of its cabin staff, the brand did not change its decision.

\section{Limitations}

There are two main limitations of this study. First, by using typical case sampling, this study has only been directed to one brand. Second, due to geographical and limited time problems, interviews could not take place face to face.

\section{Conclusion}

Turkish Airlines as the first airline company of Turkey is a brand with strong cultural background and influences. It is seen as one of the most successful brands of Turkey and has demonstrated its success by becoming the best airline company of Europe in 2012. THY has a brand culture which is highly influenced by the Turkish culture. At the same time, as a strong brand THY seems to affect the Turkish culture and the perceptions about Turkish brands in a positive way. The brand defines its cultural codes as being; customer-centric, prestigious, reliable, visionary, entertaining and global. Data gathered from both interviewees and secondary data indicate the cultural codes of THY as: Turkish authenticity, hospitality, friendliness, quality, being global, cultural heritage, comfort, synthesis of the east and the west and mixture of tradition and modernity.

THY maintains the fundamental elements of its culture in all platforms but assemble these with the cultural aspects of different countries. One of the most important factors of THY's growing success stands out to be the intercultural management and brand culture. The brand is successful in handling culture in their relationships with its corporate target audiences and customers. Though, from the customer's point of view, THY is criticized of not being as successful in respecting its employees and Turkish people's choices. Also, THY's brand image is highly related with its cultural roots. The successful branding process and the positive brand image are grounded on embracing the Turkish culture. 


\section{References}

Barbu, Oana. 2012. Brand cultures: Between identity and image. Mediterranean Journal of Social Sciences 3 (9). 47-55.

Buil, Isabel and Chernatony, Leslie de and Hem, Leif E. 2009. Brand extension strategies: Perceived fit, brand type, and culture influences. European Journal of Marketing 43 (11/12). 1300-1324.

de Mooij, Marieke D. 2000. The future is predictable for international marketers. Converging incomes lead to diverging consumer behaviour. International Marketing Review 17 (2). 103-113.

de Mooij, Marieke D. and Hofstede, Geert. 2002. Convergent and divergence in consumer behavior: implications for international retailing. Journal of Retailing 78. 61-9.

Dwyer, Sean and Mesak, Hani and Hsu, Maxwell. 2005. An exploratory examination of the influence of national culture on cross-national product diffusion. Journal of International Marketing 13 (2). 1-28.

Erdem, Tülin and Swait, Joffre and Valenzuela, Ana. 2006. Brands as signals: a cross-country validation Study. Journal of Marketing 70 January. 34-49.

Firat, A. Fuat and Dholakia, Nikilesh. 2006. Theoretical and philosophical implications of postmodern debates: Some challenges to modern marketing. Marketing Theory 6 (2). 123-62.

Harun, Amran, Wahid, Nabsiah Abdul, Mohammad, Osman and Ignatius Jenny. 2011. The concept of culture of brand origin (COBO): A new paradigm in the evaluation of origin effect. International Journal of Academic Research in Business and Social Sciences 1 (3). 282-290.

Hofstede, Geert. 1980. Culture's consequences: International differences in work-related values. Beverly Hills, CA: Sage Publications. Holt, Douglas B. 2003a. What becomes an icon most? Harvard Business Review 81 (3). 43-9.

Holt, Douglas B. 2003b. Brands and Branding. Cultural Strategy Group: http://culturalstrategygroup.com/wpcontent/uploads/2010/10/brands-and-branding-csg.pdf.

Kapferer, Jean-Noel. (2008). The new strategic brand management: Creating and sustaining brand equity long term. (fourth edition). Great Brittain: Kogan Page Publishers.

Küçükerdoğan, Rengin \& Zeybek, Işıl \& Ekin, Volkan. 2011. The global advertising of a local brand in terms of analyzing the visual content: Turkish Airlines Globally Yours advertising campaign. The Turkish Online Journal of Design, Art and Communication 1 (1). 40-51.

Patton, Michael Quinn. 2002. Qualitative research and evaluation methods. USA: Sage Publications.

Roth, Martin S. 1995. The effects of culture and socioeconomics on the performance of global brand image strategies. Journal of Marketing Research 32 (2). 163-75.

Schroeder, Jonathan E. 2009. The cultural codes of branding, Marketing Theory 9 (1). 123-126.

Schroeder, Jonathan E. 2007. Brand culture: Trade marks, marketing and consumption, In Ginsburg Jane C., Bently Lionel, Davis Jennifer (eds.). Trade marks and branding: An interdisciplinary critique, 161-176. Cambridge: Cambridge University Press.

Leo, Cheryl and Bennett, Rebekah and Hartel, Charmine.E.J. 2005. Cross-cultural differences in consumer decision-making styles. Cross Cultural Management 12 (3) 32-63.

Närvänen, Elina. 2011. The brand as a cultural network hub: acknowledging multiple parties in branding, Teoksessa Nordic Academy of Management Conference. 1-21.

Witkowski, Terrence H. and Wolfinbarger, Mary F. 2002 Comparative service quality: German and American ratings across service settings. Journal of Business Research 55. 875-81.

Yan, Jinsong. 2011. A study on the connotation of brand culture and the updated advantages of developing brand culture, Management and Service Science (MASS) International Conference Aug. 2011. 1-4.

Yang, Yuekun. 2010. The construction of brand culture based on corporate culture. International Journal of Business and Management 5 (4). 223-226.

......http://www.turkishairlines.com, Received: October 2012. 